\title{
EXPLORING THE LEVEL AND PRIMARY CAUSES OF PUBLIC SPEAKING ANXIETY AMONG ENGLISH DEPARTMENT STUDENTS
}

\author{
Kenti Sugiyati ${ }^{1}$, Lilia Indriani ${ }^{2}$ \\ Universitas Tidar ${ }^{l, 2}$ \\ kenti.sugiyati48@gmail.com \\ indriani@untidar.ac.id
}

\begin{abstract}
English public speaking anxiety is a crucial issue experienced by students and it needs to be coped with acknowledging the importance of public speaking proficiency concerning today's demands. As EFL students, many studies have found that they encountered a considerable level of public speaking anxiety in which significantly affects their speaking quality. Therefore, measuring students' public speaking anxiety is essential since it can help both the students and teachers to know the level and primary causes of public speaking anxiety so that effective strategies can be designed to overcome this particular issue. Hence, the researchers attempt to investigate the level and primary causes of EFL students' public speaking anxiety. This present study participated by 34 third-semester students of the English Department at Universitas Tidar. In collecting the data regarding the public speaking anxiety level, the researchers used the Public Speaking Class Anxiety Scale (PSCAS) proposed by Yaikhong \& Usaha (2012). Furthermore, the results from the questionnaire are delineated to explore the causes of public speaking anxiety. The study found that $58.8 \%$ of students experienced a medium level of public speaking anxiety. In addition, most of the students agreed that fear of negative evaluation becomes the major anxiety-provoking factor following by communication apprehension and test anxiety-lastly, only almost half of the students' experience comfort in speaking English.
\end{abstract}

Keywords: anxiety level, anxiety-provoking factors, EFL students, public speaking class anxiety

\section{To cite this article:}

Sugiati, K. \& Indriani, L. (2021). Exploring the Level and Primary Causes of Public Speaking Anxiety among English Department Students. Journal of Research on Language Education, 2(1), 57-66.

\section{INTRODUCTION}

Public speaking refers to a type of communication addressed in front of many people and usually in the form of a lecture or speech. It proposes to deliver information, influence, or entertain the audiences. Astuti (2011) revealed that public speaking is an approach to transferring a message or idea to people to build their understanding of the information or change the audiences' point of view or opinion. Moreover, Beebe and Susan J. Beebe (2013) pointed out that public speaking is the process of speaking to a group of people with a unique point of view. Being able to master the art of public speaking and public appearances will differentiate and bring the speaker above the average individuals whose ideas, quality, and features are rarely concerned and rearranged by society as potential, which deserves their attention (Novaković \& Teodosijević, 2017). It implies that public speaking can help the speakers improve their quality and facilitate them to transform their ideas, which may benefit others. Its importance is in line with Baccarani \& Bonfanti (2015) study, which claimed that public speaking is a persistent and vital activity in today's workplace. Public speaking abilities can support an individual's career, and successful speakers are often recognized as leaders (Rowh, 2009). Therefore, it can be viewed that public speaking is an essential ability to master, considering today's demands in many kinds of fields.

As public speaking requires the speaker to stay in front of people whose focus of their eyes and attention are on the speaker; thus, it can drive the speaker to experience pressure either before or during giving the speech. Consequently, this pressure leads the speaker to feel like they shouldn't make any mistakes, which makes them tense and experience anxiety. Sadiq (2017) affirmed that anxiety was considered a comprehensively measured aspect in foreign language context for the past few decades. Suleimenova (2012) discovered that speaking anxiety occurs among the Kazakh second-year university students, and students who have higher anxiety encountered obstacles to make a better performance. Furthermore, public speaking anxiety can be one of the critical constraints people have to deal with when they feel anxious about speaking. They prefer to evade 
situations where they have to perform. Still, when they face such situations, they endure extreme stress and anxiety (Hidayoza et al., 2019). When the speaker encounters speaking anxiety in their public speech, it will affect their speaking quality, leading them to feel embarrassed if they make mistakes and further drive them to eliminate the chance to do a public speaking activity. As stated by Davidson (2002), public speaking customarily constructs the top 10 lists of things people would tend to avoid. Generally, people negatively evaluate and appraise those who display their fears concerning public speaking and unable to create a strong image through convinced gestures (Katz, 2000).

Considering the importance of public speaking for students both for educational purposes and future careers, therefore, they are expected to have excellent public speaking ability. Bodie (2010), public speaking is a crucial part of leadership communication, an essential workplace skill, and the ability to make good presentations is frequently becomes a substantial part of work responsibilities. Therefore, many universities include the Public Speaking course as one of the compulsory subjects that students must enroll in, such as in the English Education Study Program at Universitas Tidar. This course facilitates the third-semester students to learn the nature of public speaking and the opportunities to speak in front of the class. However, as EFL students, they might experience a more challenging situation when required to deliver their speech in front of others. This often leads to what is called anxiety; in this case, it is specifically called Public Speaking Anxiety (PSA). Students who experienced a low level of anxiety can perform better and actively participate in the classroom (Bashosh et al., 2013). Nevertheless, Tiyas et al. (2020) stated that students try to avoid public speaking as much as possible since they feel that factors forced them to avoid public speaking. Spijck (2011) found out almost eighty out of every hundred people encountered public speaking anxiety at a small or large scale. Public speaking is such a commonplace encounter by several people, including students in a specific case, and becomes one of the barriers that students experience in their academic process (Pratama, 2018). Therefore, they cannot actively share their ideas and opinions loudly due to factors such as fear of making mistakes, negative evaluation, and minimum preparation.

EFL students' public speaking anxiety can be derived from several factors. Hortwiz, et al (1986) stated that three different situations arouse foreign language anxiety, those are communication apprehension (CA), fear of negative evaluation (FNE), and test anxiety (TA). First, communication apprehension is a type of anxiety that evokes speakers' fear of making a communication transaction (DeVito, 1986; Horwitz et al., 1986). In communication apprehension, the students feel uncomfortable, shy, and fear when they have to engage in real communication with other people (Horwitz et al., 1986). Several cases of communication apprehension influence the students' difficulty not only in speaking with others but also in listening to or learning the spoken messages (Horwitz et al., 1986). The level of communication apprehension (CA) is based on EFL students' levels of proficiency. Thus, it can be said that CA may be the major source of anxiety for EFL low proficiency students. In contrast, it is not the major source of anxiety for high proficiency students (Aydin, 2016). Furthermore, Horwitz et al., (1986), fear of negative evaluation deals with students' apprehension of others' evaluation. It emerges them to avoid evaluation situations and build the expectation that others would evaluate them negatively. This type of anxiety is not limited to test-taking situations; instead, it may occur in any social, evaluative situation, including an interview for a job or speaking in a second or foreign language class. Lastly, test anxiety refers to the students' fear of failure in a test. It arises since the students have thoughts that the only acceptable performance in a test is when they can do it perfectly. Test anxiety holds an important role in affecting students learning outcomes, several feelings such as fear of failure or unpleasant experience are forms of test anxiety that happens in students' minds (Horwitz et al., 1986).

Measuring the level of students' public speaking is highly recommended as it can help the students to know how the degree of their anxiety and what are the major causes influenced their anxiety. It can also provide the teacher with information to design effective strategies to overcome students' public speaking anxiety. As the study executed by Sikandar (2017) found that the public anxiety faced by students is mostly caused by the fear of speaking in front of others, it is seen by $75 \%$ of the students who agree with the statement whether or not they experience fear of public speaking. Furthermore, Hidayoza et al. (2019), in their study entitled "Level of Public Speaking Anxiety and Coping Strategy used by English Debaters at Unit Kegiatan Bahasa Asing in dealing with English Debate," discovered that English department debaters, Unit Kegiatan Bahasa Asing, Universitas Negeri Padang, experienced a medium level of public speaking anxiety. It is counted by $50 \%$ of the respondents who claimed that they experienced public speaking anxiety, particularly when joining debates. Sulastiani (2017), in her study, found that $82.5 \%$ of students experienced a medium level of fear and anxiety when they speak English in public speaking class. This study revealed that students' anxiety had negative impacts on their performance in public speaking class, such as forgetting their speech and disarrange their speech preparation, feeling confused, and often break off their speech, also make them uncomfortable to speak English in public speaking class. Pratiwi et al. (2017), in their study, showed that 52\% of the third-semester students of the English Education Study Program at Sriwijaya University (52\%) experienced a medium level of speaking 
anxiety. It demonstrates that most of the students face a considerable level of public speaking anxiety in which it needs to be kept being evaluated whether strategies implemented are prevalent to cope with their anxiety in public speaking.

Determining the importance of measuring students' level of public speaking anxiety motivated the researchers to investigate English public speaking anxiety faced by the third-semester students of the English Department at Universitas Tidar. This present study also aims to explore the major causes that influenced their public speaking class anxiety. By knowing the level and major caused of students' public speaking class anxiety, it is expected that the next research conducted will investigate the strategies that can effectively help students to reduce their problem with public speaking anxiety. Hence, this current study intended to answer the following research questions.

1. What are the levels of public speaking class anxiety (PSCA) experienced by the third-semester students of the English Department at Universitas Tidar?

2. What are the primary factors that influence the public speaking class anxiety (PSCA) among thirdsemester students of the English Department at Universitas Tidar?

\section{RESEARCH METHOD}

This present study aims to expose the level and the major factors influencing students' public speaking class anxiety. Therefore, a quantitative descriptive method was utilized in this study since the data were presented in numerical and descriptive form. Aliaga and Gunderson (2002) elaborated quantitative research as an inquiry into a social problem that reveals phenomena by collecting numerical data identified using mathematically based methods, for instance, particular statistics. Sugiyono (2005), a descriptive method is an approach that is designed to elaborate or analyze research findings but is not used to make broader.

The participants of this study consist of 34 third-semester students of the Education Study Program Faculty of Teacher Training and Education at Universitas Tidar. Furthermore, the final version of the Public Speaking Class Anxiety Scale (PSCAS) proposed by Yaikhong and Usaha (2012) was used to collect the data regarding students' level of public speaking anxiety. Yaikhong and Usaha (2012) stated that the PSCAS can provide a respectable preliminary internal consistency at .84 after being piloted with 76 participants. It showed a construct composition around the speaking component in a public speaking class setting. This type of questionnaire consists of 17 items with positive and negative statements to determine students' public speaking class anxiety levels. Every item was remarked on a five-point Likert Scale. For the positive statement items, the scale is ranging from 5 "Strongly Agree" to 1 "Strongly Disagree." There are four positive statement items in PSCAS Questionnaire (item 4, 8, 10, and 12), and to adjust the scores for those items, Liu and Jackson in Yahikong and Usaha (2012) offered to adjust the values assigned to different alternatives from "Strongly Disagree" to "Strongly Agree" so that the response "Strongly Disagree" received a score of 5 instead of 1 and vice versa. Additionally, to identify the causes of students' public anxiety, the results reported from the questionnaire will be static explained since it contains four major causes of anxiety, namely communication apprehension (CA), test anxiety (TA), fear of negative evaluation (FNE), and comfort in speaking English (CNE).

Table 1. The Scoring Scale of PSCAS

\begin{tabular}{llc}
\hline Positive Attitude Statement Score & & Negative Attitude Statement Score \\
\hline & Strongly Agree & 5 \\
2 & Agree & 4 \\
3 & Undecided & 3 \\
4 & Disagree & 2 \\
5 & Strongly Disagree & 1 \\
\hline
\end{tabular}

The scoring interval was cited in PSCAS (Public Speaking Class Anxiety Scale) by Yaikhong and Usaha (2012) to examine the level of anxiety.

Table 2. The Scoring Interval

\begin{tabular}{ll}
\hline Interval score & Category \\
\hline$>68$ & High anxiety \\
$50-68$ & Medium anxiety \\
$\leq 50$ & Low Anxiety \\
\hline
\end{tabular}




\section{FINDINGS AND DISCUSSION}

\section{The Level of Students' Public Speaking Class Anxiety}

As mentioned before, the researchers adopted the final version of the PSCAS questionnaire proposed by Yaikhong and Usaha (2012). The results of the PSCAS questionnaire reflected from 34 samples of thirdsemester students of the English Department at Universitas Tidar shows that the highest score of level anxiety was derived from the medium score. It is displayed in Table 3 that $58.8 \%$ of students have a medium level of public speaking class anxiety. Following this, $14.7 \%$ of students experienced a low level of public speaking class anxiety, and only $2 \%$ of students encountered a high level of anxiety.

Table 3. Students' Level of Public Speaking Class Anxiety

\begin{tabular}{llll}
\hline $\begin{array}{l}\text { Level of speaking } \\
\text { anxiety }\end{array}$ & Scores & Percentage & Frequencies \\
\hline $\begin{array}{l}\text { High level of speaking } \\
\text { anxiety (total score }\end{array}$ & 368 & 14.7 & 5 \\
$>68$ ) & 58.8 & 20 \\
$\begin{array}{l}\text { Moderate level of } \\
\text { speaking }\end{array}$ & & \\
$\begin{array}{l}\text { anxiety (total score 50- } \\
68 \text { ) }\end{array}$ & 2 & 9 \\
$\begin{array}{l}\text { Low level of speaking } \\
\text { anxiety (total score }\end{array}$ & & & \\
$<50$ ) & 1198 & 100 & 34 \\
\hline Total & 1.975 & speaking andiety, students likely to focus
\end{tabular}

Peplau (1989) found that at a medium level of speaking anxiety, students likely to focus exclusively on the stressful situation directly in front of them and ignore other tasks. Still, on his finding, Peplau (1989) stated that students who have medium anxiety level might experience a faster heartbeat, dry mouth, sweating, and stomach pain or nausea in which it would make them only focus on their performance. Melouah (2013) identified the sources and levels of 54 Algerian EFL university students' oral performance anxiety, and the study indicated that students experience a moderate level of speaking anxiety due to low language proficiency. Horwitz and Young (1991), as it is cited in Rachmawati (2020), affirmed that students who experienced moderate anxiety levels are caused by less confidence in a certain condition. Therefore, to explore the major causes of the public speaking anxiety of the third-semester students of the English Department at Universitas Tidar, the researchers will explain the data obtained from the PSCAS questionnaire.

\section{The Factors of Students' Public Speaking Class Anxiety}

To answer the second research question, the researchers investigated the factors arousing public speaking class anxiety among English Department students at Universitas Tidar by calculating and combining the percentage of 'strongly agree' and 'agree' to get the whole score of agreement of the items in PSCAS questionnaire. To accelerate analyses and discussion, the researchers shorted the data provided in Table 4, 5, 6, 7 in a descending order where the frequencies are listed from highest to the lowest score. Furthermore, public speaking class anxiety comprises communication apprehension, test anxiety, fear of negative evaluation, and comfort in using English, which forms around the speaking component in a public speaking class (Yaikhong \& Usaha, 2012).

\section{Communication Apprehension Factor}

Table 4. Frequencies and percentages of Communication Apprehension (CA) items

\begin{tabular}{|c|c|c|c|c|c|c|c|}
\hline No. & Items & SD & $\mathbf{D}$ & $\mathbf{N}$ & $\mathbf{A}$ & $\overline{\text { SA }}$ & $\overline{\mathrm{A}+\mathrm{SA}}$ \\
\hline \multirow[t]{3}{*}{2.} & I start to panic when I have to speak English without preparation in advance. & & & & & & \\
\hline & $\mathrm{F}$ & 0 & 5 & 4 & 11 & 17 & 28 \\
\hline & $\%$ & 0 & 14.7 & 11.8 & 32.3 & 50 & 82.5 \\
\hline \multirow[t]{3}{*}{3.} & In a speaking class, I can get so nervous I forget things I know. & & & & & & \\
\hline & $\mathrm{F}$ & 0 & 2 & 8 & 16 & 8 & 24 \\
\hline & $\%$ & 0 & 5.9 & 23.5 & 47 & 23.5 & 70.5 \\
\hline \multirow[t]{3}{*}{5.} & I get nervous and confused when I am speaking English. & & & & & & \\
\hline & $\mathrm{F}$ & 1 & 6 & 8 & 14 & 6 & 20 \\
\hline & $\%$ & 2.9 & 17.6 & 23.5 & 41.1 & 17.6 & 58.7 \\
\hline \multirow[t]{3}{*}{15.} & I dislike using my voice and body expressively while I am speaking English. & & & & & & \\
\hline & $\mathrm{F}$ & 2 & 16 & 8 & 5 & 4 & 9 \\
\hline & $\%$ & 5.9 & 47 & 23.5 & 14.7 & 11.8 & 26.8 \\
\hline \multicolumn{2}{|c|}{ Average of $\mathrm{SA}+\mathrm{A}$} & \multicolumn{6}{|c|}{20.25} \\
\hline
\end{tabular}


From the table above, the data showed that the third-semester students experienced communication apprehension with an average frequency of 20.25 of the responses agreeing to items $2,3,5$, and 15 in which those are classified into communication apprehension factor. The highest percentage among the items is showed with the percentage of 82.5: item 2, which stated that most students agree that they start to panic when they have to speak English without preparation in advance. It demonstrates that in terms of speaking English without preparation, most students experienced anxiety. It is in line with Mak's (2011) claims that speaking in front of the class without preparation was an anxiety-provoking factor. Moreover, the researchers argued that the students' inability to communicate in English without preparation in advance is related to the lack of communicative practice; thus, they do not have alternative sources of speaking materials. Following this, $70.5 \%$ of the students agree that in a speaking class, they can get so nervous when they forget things they know: item 2. It may be derived from forgetting terms or vocabulary intent to express the ideas. MacIntyre and Gardner (1994) draw parallels between anxious students and the vocabulary learning process. They emphasized that anxious students frequently forget the vocabulary of the target language in-class activities and in oral communications.

Furthermore, $58.7 \%$ of students agree that they get nervous and confused when they are speaking English, as in item 5. Lastly, 26.8\% of students dislike using their voice and body expressively while speaking English, item 15. It demonstrates that while speaking English, students feel less confident about their voice and how they express their body language. Thus, as communication apprehension related to the fear of communication with others (Horwitz et al., 1986), it is not surprising that learners consider speaking in front of other people one of the most common sources of anxiety, especially if proficiency in the foreign language is perceived as limited (Young, 1999).

\section{Fear of Negative Evaluation Factor}

\begin{tabular}{|c|c|c|c|c|c|c|c|}
\hline No. & Items & SD & $\mathbf{D}$ & $\mathbf{N}$ & $\mathbf{A}$ & $\overline{\mathbf{S A}}$ & $\mathbf{A + S A}$ \\
\hline \multirow[t]{3}{*}{9.} & I can feel my heart pounding when I am going to be called on. & & & & & & \\
\hline & $\mathrm{F}$ & 0 & 0 & 5 & 13 & 17 & 30 \\
\hline & $\%$ & 0 & 0 & 14.7 & 38.2 & 50 & 88.2 \\
\hline \multirow[t]{3}{*}{14} & I feel anxious while I am waiting to speak English. & & & & & & \\
\hline & $\mathrm{F}$ & 1 & 2 & 9 & 15 & 8 & 23 \\
\hline & $\%$ & 2.9 & 5.9 & 26.5 & 44.1 & 23.5 & 67.6 \\
\hline \multirow[t]{3}{*}{6.} & I am afraid that other students will laugh at me while I am speaking English. & & & & & & \\
\hline & $\mathrm{F}$ & 5 & 6 & 4 & 12 & 8 & 20 \\
\hline & $\%$ & 14.7 & 17.6 & 11.8 & 35.2 & 23.5 & 58.7 \\
\hline \multirow[t]{3}{*}{11.} & It embarrasses me to volunteer to go out first to speak English & & & & & & \\
\hline & $\mathrm{F}$ & 1 & 7 & 8 & 13 & 6 & 19 \\
\hline & $\%$ & 2.9 & 20.5 & 23.5 & 38.2 & 17.6 & 55.8 \\
\hline \multirow[t]{3}{*}{13.} & Certain parts of my body feel very tense and rigid while I am speaking English. & & & & & & \\
\hline & 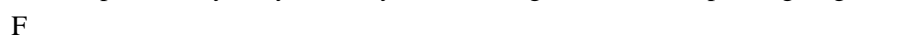 & 1 & 3 & 12 & 14 & 5 & 19 \\
\hline & $\%$ & 2.9 & 8.8 & 35.2 & 41.1 & 14.7 & 55.8 \\
\hline \multirow[t]{3}{*}{16.} & I have trouble coordinating my movements while I am speaking English. & & & & & & \\
\hline & $\mathrm{F}$ & 1 & 9 & 11 & 8 & 6 & 14 \\
\hline & $\%$ & 2.9 & 26.5 & 32.3 & 23.5 & 17.6 & 41.1 \\
\hline \multicolumn{2}{|c|}{ Average of $\mathrm{SA}+\mathrm{A}$} & \multicolumn{6}{|c|}{20.83} \\
\hline
\end{tabular}

Table 5 displays that the average frequency of fear of negative evaluation (FNE) experienced among English department students is 20.83. By investigating the items included in this particular factor, the data shows that $88.2 \%$ of students experienced heart pounding when they are going to be called on, item 9 . It is the highest percentage of an anxiety-provoking factor in FNE. Following this, 67.6 of students agree that they feel anxious while waiting to speak English, item 14. From these results, it can be withdrawn that the students suffer from rapid heartbeat when they are waiting for their turn to speak English in front of the class. Next, 58.7\% of students respond that they are afraid if others will laugh at them while speaking English. It might be due to the fear of making mistakes while performing their speaking, such as mispronouncing and forgetting things so that they made too many spaces or unnecessary fillers. Additionally, students $55.8 \%$ of students feel that it embarrasses them to volunteer to go out first to speak English, item 11. It is following Gregersen and Horwitz (2002), who revealed that FNE affects the behavior of students during communication-oriented situations since they tend to limit their participation in any type of tasks that required them to peer or teacher evaluation. Furthermore, $55.8 \%$ of students experienced certain parts of their body feel very tense and rigid while speaking English. Gibson (1992), argued that public speaking anxiety is manifested in various ways such as blood pressure, trembled hands, weakness, anxiousness, forgetting the prepared material, and avoiding eye contact with the audience. Lastly, Table 5 shows that $41.1 \%$ of students have trouble in coordinating their movements while speaking English. It is because they fully concentrate on their term of speaking; hence, they might encounter 
difficulty to move some part of their body expressively, for instance, head or hand movement (Kurniawanti, 2017).

\section{Test Anxiety Factor}

\begin{tabular}{|c|c|c|c|c|c|c|c|}
\hline No. & Items & SD & D & $\mathbf{N}$ & $\mathbf{A}$ & SA & $\mathbf{A}+\mathbf{S A}$ \\
\hline \multirow[t]{3}{*}{7.} & $\begin{array}{l}\text { I get nervous when the English teacher asks me to speak English which I have } \\
\text { prepared in advance. }\end{array}$ & & & & & & \\
\hline & $\mathrm{F}$ & 3 & 5 & 8 & 11 & 8 & 19 \\
\hline & $\%$ & 8.8 & 14.7 & 23.5 & 32.3 & 23.5 & 55.8 \\
\hline \multirow[t]{3}{*}{17.} & Even if I am very well prepared, I feel anxious about speaking English. & & & & & & \\
\hline & $\mathrm{F}$ & 1 & 4 & 12 & 11 & 7 & 18 \\
\hline & $\%$ & 2.9 & 11.8 & 35.2 & 32.3 & 20.5 & 52.8 \\
\hline \multirow[t]{3}{*}{1.} & I never feel quite sure of myself while I am speaking English. & & & & & & \\
\hline & $\mathrm{F}$ & 0 & 6 & 13 & 13 & 3 & 16 \\
\hline & $\%$ & 0 & 17.6 & 38.2 & 38.2 & 8.8 & 47 \\
\hline
\end{tabular}

In test anxiety factor, Table 6 demonstrates that $17.7 \%$ of students experienced test anxiety in public speaking class, and they agree that the most causes of anxiety are derived when the teacher asks them to speak English although they have prepared in advance, see item 7. Closely related to this, the response on item 17 shows that $52.8 \%$ of students feel anxious about speaking English, even if they are well prepared. Moreover, the table shows that $47 \%$ of students never feel quite sure of themselves while speaking English. Considering these results, it can be said that those factors are linked to their self-confidence. Item 7 and 17 show that even though they have prepared in advance or well prepared before speaking English, they still experience a considerable level of anxiety. Toubot et al., (2018) uttered that self-confidence is one of the personal factors that exceedingly associate with anxiety. Students who lack self-confidence will break down on practicing their target language since they would be afraid of making mistakes and feeling humiliated (Leong \& Ahmadi, 2017). Students who feel less confident will affect their performances; they will not be sure of themselves because of afraid of making mistakes and expect to receive unpleasant evaluations from their audience. Therefore, personal perceptions play an essential role in building their self-confidence. It is in line with Park and Lee's (2005) suggestion that judgments and self-evaluation on personal value and worth are some of the traits of self-confidence. Moreover, Zia and Norrihan (2015) mentioned that teachers' teaching methods and classroom atmosphere are determined as the primary factors for diminishing students' speaking anxiety. Therefore, creating a supportive and encouraging environment inside the classroom among the students and their teachers is needed to elevate students' selfconfidence, alleviating their anxiety, and then leads them to better in learning and enables students to improve their speaking performance.

\section{Comfort in Speaking English Factor}

Table 7. Frequencies and percentages of Comfort in Speaking English (CNE) items

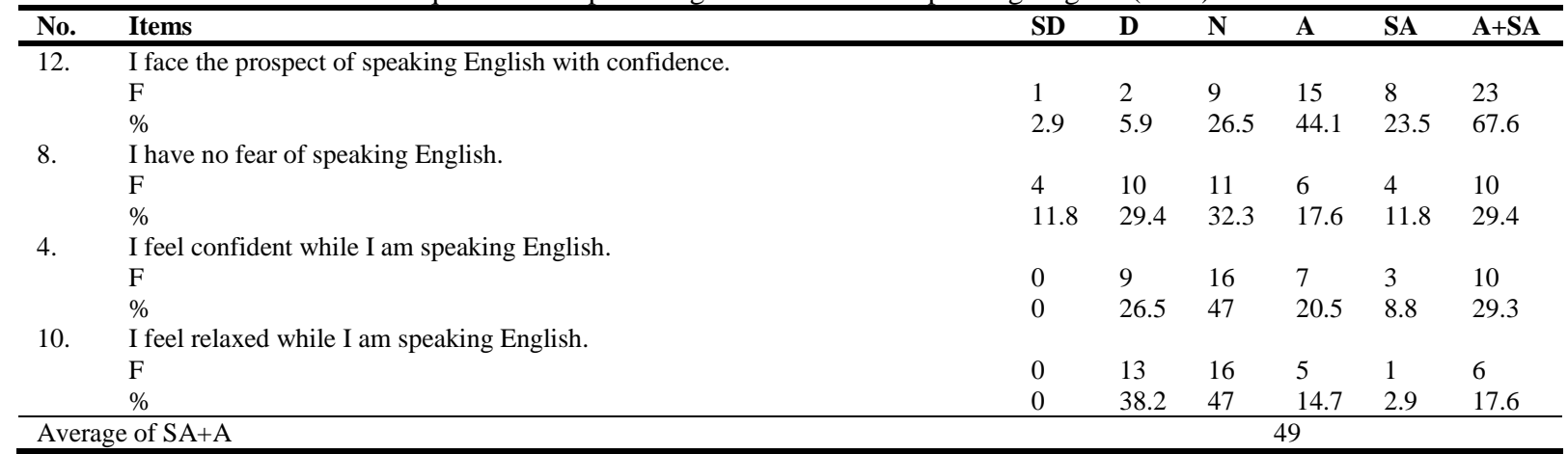

The last factor is related to students' perspectives toward English public speaking class activity. Table 7 shows that the average frequency percentage of the comfort in speaking English is 49 among students who agree with items in this factor: item 12,4, 8 , and 10. This frequency demonstrates that almost half of the number of students' experience comfort in speaking English. It can be viewed from the data on item 4 that only $29.4 \%$ have no fear of speaking English; 29.3\% of students feel confident while speaking English, item 4; and only $17.6 \%$ of students feel relaxed while speaking English, item 10. However, the data on item 12 appears that $67.6 \%$ of students face the prospect of speaking English with confidence. It represents students who still believe that they 
can perform English public speaking confidently. Hence, to increase student's oral achievement in English and decrease the negative feelings, teachers should create a natural classroom atmosphere, as the sources of language anxiety are involved in and be a part of the impacts of unnatural classrooms (Young, 1991). Furthermore, Boonkit (2010) conducted a study on the factors promoting the development of students' speaking skills. The results showed that the implementation of relevant activities for speaking skills can be an effective strategy to avelliate speakers' anxiety. His finding also mentioned that the freedom of topic choice urged the participants to feel comfortable, convinced to speak English, and elevated EFL students speaking confidence.

\section{CONCLUSION}

From the overall finding and discussion presented, this current study concluded that the third-semester students of the English Department at Universitas Tidar experienced a medium level of public speaking anxiety. The level of anxiety among students surveyed in this research is $58.8 \%$. Furthermore, the data regarding factors of anxiety experienced by students are further analyzed from the PSCAS questionnaire proposed by Yaikhong and Usaha in which is initially used to examine students' level of anxiety. From the four components of factor analysis, the researchers viewed the three components as the anxiety-provoking factors while the rest as students' perspectives on English speaking. The finding shows that from the three components of anxiety factors, fear of negative evaluation (FNE) ranked in the highest level of the causes of anxiety. It is calculated that the average percentage of FNE is 20.83 of students who agree with the items on this factor. Following this, the communication apprehension (CA) was placed in the second rank with an average percentage of 20.25 students who responded of agreement with the items. Besides, test anxiety (TA) is positioned in the third rank of anxietyprovoking factor, with an average percentage of 17.7 of students agreeing with the items. Lastly, in the component of comfort in speaking English (CNE), only 49\% of students agree that they feel comfortable in speaking English. From this study, the researchers expected that there are effective strategies designed to help students alleviate their anxiety so that they can perform better in public speaking skills both in and outside the classroom.

\section{REFERENCES}

Aliaga, M., \& Gunderson, B. (2002). Interactive Statistics. Thousand Oaks: Sage.

Astuti, K. N. (2011). Jurus Kilat Jago Public Speaking Secara Otodidak,. Laskar Aksara.

Aydin, S. (2016). A Qualitative Research on Foreign Language Teaching Anxiety. The Qualitative Report, 21(4), 629-642.

Baccarani, C., \& Bonfanti, A. (2015). Effective public speaking: A conceptual framework in the corporate-communication field. Corporate Communications: An International Journal, 20(3), 375-390.

Bashosh, S., Nejad, M. A., Rastegar, M., \& Marzban, A. (2013). The relationship between shyness, foreign language classroom anxiety, willingness to communicate, gender, and EFL proficiency. Theory and Practice in Language Studies, 3(11), 2098-2106. https://doi.org/https://doi.org/10.4304/tpls.3.11.2098-2106

Beebe, S. A., \& Beebe, S. J. (2013). Public Speaking Handbook (4th Edition). Pearson.

Bodie, G. (2010). A racing heart, rattling knees, and ruminative thoughts: Defining, explaining, and treating public speaking anxiety. Communication Education, 59(1), 70-105.

Boonkit, K. (2010). Enhancing the Development of Speaking Skills for Non-Native Speakers of English. Procedia Social and Behavioral Sciences, 2(2010), 1305-1309.

Davidson, J. (2002). The Complete Guide to Public Speaking. John Wiley \& Sons, Inc.

DeVito, J. A. (1986). The Interpersonal Communication Book (4th ed.). Harper and Row Publishers.

Gregersen, T., \& Horwitz, E. K. (2002). Language learning and perfectionism: Anxious and non-anxious language learners' reactions to their own oral performance. Modern Language Journal, 86(4), 562-570. https://doi.org/https://doi.org/10.1111/1540-4781.00161

Hanna, M. S., \& Gibson, J. W. (1992). Public speaking for personal success (3rd ed). William C. Brown.

Hidayoza, P., Amri, Z., \& Wahyuni, D. (2019). Level of Public Speaking Anxiety and Coping Strategy used by English Debaters at Unit Kegiatan Bahasa Asing in dealing with English Debate. 8(1).

Horwitz, E. K., \& Young, D. (1991). Language Learning Anxiety: From Theory and Research to Classroom Implications. Prentice-Hall.

Horwitz, E. K., Horwitz, M. B., \& Cope, J. (1986). Foreign Language Classroom Anxiety. In Source: The Modern Language Journal (Vol. 70, Issue 2).

Katz, L. (2000). Public Speaking Anxiety. In UTM Counseling and Career Services (Vol. 1). University of Tennessee. http://sp.myconcorde.edu/sites/Portland-OR/LRC/Shared Documents/Public Speaking.pdf

Kurniawanti, B. St. (2017). A Study of Anxiety in Speaking Class of the Second Semester Students in English Education Department at UIN Alauddin Makassar. Undergraduate (S1) thesis, Universitas Islam Negeri Alauddin Makassar.

Leong, L. M., \& Ahmadi, S. M. (2017). An analysis of factors influencing learners' English speaking skill. International Journal of Research in English Education, 2(1), 34-4.

MacIntyre, P. D., \& Gardner, R. C. (1994). The Subtle Effects of Language Anxiety on Cognitive Processing in the Second Language. Language Learning, 44(2), 283-305. https://doi.org/10.1111/j.1467-1770.1994.tb01103.x

Mak, B. (2011). An exploration of speaking-in-class anxiety with Chinese ESL learners. System, 39(2), 202-214.

Melouah, A. (2013). Foreign language anxiety in EFL speaking classrooms: A case study of first-year LMD students of 
English at Saad Dahlab University of Blida, Algeria. Arab World English Journal, 4(1), 64-76.

Novaković, N., \& Teodosijević, B. (2017). Basics of public speaking. Bizinfo Blace, 8(2), $33-46$. https://doi.org/10.5937/bizinfo1702033n

Park, H., \& Lee, A. R. (2005). L2 learners' anxiety, self-confidence and oral performance. The 10th Conference of PanPacific Asso-Ciation of Applied Linguistics, Japan.

Peplau, H. E. (1989). Anxiety, Self, and Hallucination. In Interpersonal theory in Nursing Practice. Springer.

Pratama, R. (2018). A Student 's strategies to overcome Speaking Anxiety in Public Speaking Class.

Pratiwi, I. A., Mirizon, S., \& Zuraida. (2017). An analysis on students' perception toward their speaking anxiety of English Education Study Program at Sriwijaya University. 2007, 334-342.

Rachmawati, D. I., \& Jurianto, J. (2020). Investigating English Department Students' Foreign Language Speaking Anxiety: a Case Study in Universitas Airlangga, Indonesia. Social Sciences, Humanities and Education Journal (SHE Journal), 1(2), 22. https://doi.org/10.25273/she.v1i2.6624

Rowh, M. (2009). Speak out! Everyone can benefit from public speaking skills. Career World, a Weekly Reader Publication, $38(3), 6-9$.

Sadiq, J. M. (2017). Anxiety in English Language Learning: A Case Study of English Language Learners in Saudi Arabia. English Language Teaching, 10(7), 1. https://doi.org/10.5539/elt.v10n7p1

Sikandar, A. (2017). Anxiety Level in Students of Public Speaking: Causes and Remedies. Journal of Education and Educational Development, 4(1), 94-110.

Spijck, B. V. (2011). Overcoming fear of public speaking. https://coachcampus.com/coach-portfolios/researchpapers/\%0Ajoana-reis-an-approach-for-coaches/

Sugiyono. (2005). Memahami Penelitian Kualitatif. Alfabeta

Sulastiani. (2017). Students' perception toward Psychological Problems faced in Public Speaking Class of English Department. Muhammadiyah University of Makassar.

Suleimenova, Z. (2012). Speaking anxiety in a Kazakhstani foreign language classroom. Sino-US English Teaching, 9(12), $1766-1774$.

Tiyas, A., Nurhidayah, Y., \& Herdiawan., R. D. (2020). “Why I can’t speak up?”: Students' Anxiety in Public Speaking. Journal of English Language Learning (JELL), 103.

Toubot, A. M., Hock Seng, G., \& Binti Atan Abdullah, A. (2018). Examining Levels and Factors of Speaking Anxiety among EFL Libyan English Undergraduate Students. International Journal of Applied Linguistics and English Literature, 7(5), 47. https://doi.org/10.7575/aiac.ijalel.v.7n.5p.47

Yaikhong, K., \& Usaha, S. (2012). A Measure of EFL Public Speaking Class Anxiety: Scale Development and Preliminary Validation and Reliability. 5(12), 23-35. https://doi.org/10.5539/elt.v5n12p23

Young, D. J. (1991). Creating a low- anxiety classroom environment: What does language Anxiety Research Suggest? The Modern Language Journal, 75(4), 426-437.

Young, Dolly J. (1999). A Perspective on foreign language learning: From body to mind to emotion. In Affect in foreign language and second language learning (Young, D.). McGraw-Hill.

Zia, Z., \& Norrihan, S. (2015). EFL learners' levels of class -room performance anxieties and their causes in class-room speaking activities in Afghanistan. International Journal of English and Education, 4(1), 239-249. 


\section{APPENDIX}

The Final Version of PSCAS Questionnaire

\begin{tabular}{|c|c|c|c|c|c|c|}
\hline \multirow{2}{*}{$\begin{array}{c}\text { No } \\
\text { Item }\end{array}$} & \multirow[b]{2}{*}{ Statements } & \multicolumn{5}{|c|}{ Opinion } \\
\hline & & $\begin{array}{l}\text { (5) } \\
\text { Strongly } \\
\text { Agree }\end{array}$ & (4) Agree & $\begin{array}{l}\text { (3) } \\
\text { Undecided }\end{array}$ & $\begin{array}{l}(2) \\
\text { Disagree }\end{array}$ & $\begin{array}{l}\text { (1) } \\
\text { Strongly } \\
\text { Disagree }\end{array}$ \\
\hline 1 & $\begin{array}{l}\text { I never feel quite sure of myself while I } \\
\text { am speaking English. }\end{array}$ & & & & & \\
\hline 2 & $\begin{array}{l}\text { I start to panic when I have to speak } \\
\text { English without a preparation in advance. }\end{array}$ & & & & & \\
\hline 3 & $\begin{array}{l}\text { In a speaking class, I can get so nervous I } \\
\text { forget things I know. }\end{array}$ & & & & & \\
\hline 4 & $\begin{array}{l}\text { I feel confident while I am speaking } \\
\text { English. }\end{array}$ & & & & & \\
\hline 5 & $\begin{array}{l}\text { I get nervous and confused when I am } \\
\text { speaking English. }\end{array}$ & & & & & \\
\hline 6 & $\begin{array}{l}\text { I am afraid that other students will laugh at } \\
\text { me while I am speaking English. }\end{array}$ & & & & & \\
\hline 7 & $\begin{array}{l}\text { I get nervous when the English teacher } \\
\text { asks me to speak English which I have } \\
\text { prepared in advance. }\end{array}$ & & & & & \\
\hline 8 & I have no fear of speaking English. & & & & & \\
\hline 9 & $\begin{array}{l}\text { I can feel my heart pounding when I am } \\
\text { going to be called on. }\end{array}$ & & & & & \\
\hline 10 & I feel relaxed while I am speaking English. & & & & & \\
\hline 11 & $\begin{array}{l}\text { It embarrasses me to volunteer to go out } \\
\text { first to speak English }\end{array}$ & & & & & \\
\hline 12 & $\begin{array}{l}\text { I face the prospect of speaking English } \\
\text { with confidence. }\end{array}$ & & & & & \\
\hline 13 & $\begin{array}{l}\text { Certain parts of my body feel very tense } \\
\text { and rigid while I am speaking English. }\end{array}$ & & & & & \\
\hline 14 & $\begin{array}{l}\text { I feel anxious while I am waiting to speak } \\
\text { English. }\end{array}$ & & & & & \\
\hline 15 & $\begin{array}{l}\text { I dislike using my voice and body } \\
\text { expressively while I am speaking English. }\end{array}$ & & & & & \\
\hline 16 & $\begin{array}{l}\text { I have trouble to coordinate my } \\
\text { movements while I am speaking English }\end{array}$ & & & & & \\
\hline 17 & $\begin{array}{l}\text { Even if I am very well prepared, I feel } \\
\text { anxious about speaking English. }\end{array}$ & & & & & \\
\hline
\end{tabular}




\section{BIOGRAPHIES OF AUTHORS}

Kenti Sugiyati is undergraduate student of English Department, Faculty of Education and Teacher Training, Universitas Tidar. Her interest is on TEFL and Linguistics.

Lilia Indriani, M.Pd is a lecturer in English Department, Faculty of Education and Teacher Training, Universitas Tidar. Her interest is on technology enhanced language learning and TEFL. 